\title{
Prevalence of dysmenorrhea among University students in Northern Ghana; its impact and management strategies
}

\author{
Evans Paul Kwame Ameade ${ }^{1 *}$, Anthony Amalba ${ }^{2}$ and Baba Sulemana Mohammed
}

\begin{abstract}
Background: The period of menstruation is an eventful one for a significant number of post-pubescent females as they experience lower abdominal pains referred to as dysmenorrhea. This study conducted among female students of the Tamale campus of the University for Development Studies assessed the prevalence of dysmenorrhea, its impact on the students and treatment methods applied.
\end{abstract}

Methods: A cross-sectional study using a self-administered questionnaire was used to obtain data from 293 randomly selected female students. Data was analyzed using Graph Pad 5.01. Association between different variables was tested.

Results: The prevalence rate of dysmenorrhea was $83.6 \%$ with more than half describing their pain which lasts less than 3 days as moderate. This dysmenorrhea during menstruation affects the daily activities of up to $61.2 \%$ of respondents. Lower chronological age $\left(x^{2}=8.28 ; \mathrm{df}=2 ; p=0.016\right)$ and gynecological age $\left(x^{2}=10.09 ; \mathrm{df}=2 ; p=0\right.$. 006) were the factors that were significantly associated with the presence of dysmenorrhea. Chronological and gynecological ages, age at menarche, menstrual duration or flow level do not influence the severity of dysmenorrhea but irregular menstrual flow is significantly associated with severe dysmenorrhea $\left(x^{2}=10.54\right.$; $d f=2$; $p=0.005)$. Only $16.3 \%$ ever reported their dysmenorrhea to the hospital but increasing pain level is significantly associated with respondents visiting a hospital $\left(x^{2}=65.61\right.$; $\left.\mathrm{df}=2 ; p<0.0001\right)$ or use an allopathic medication $\left(x^{2}=32.77 ; d f=2 ; p<0.0001\right)$. Paracetamol preparation was the most common medication used notwithstanding the severity of the pain.

Conclusions: There is high prevalence of dysmenorrhea among the female students of the Tamale campus of the University for Development studies which negatively affects the daily activity of majority of them. Although, bed rest was the most common treatment method practised, paracetamol preparation was the most common allopathic drug used in self- management of their dysmenorrhea.

Keywords: Dysmenorrhea, Prevalence, Students, Management, Impact, Ghana

\section{Background}

The onset of puberty in the life of a young girl sets into motion hormonal, psychological, cognitive and physical changes which transforms the girl from a child to a sexually matured woman [1]. Menstruation, which is controlled by the hormones of the hypothalamopituitary axis and is one of the milestones of puberty in girls,

\footnotetext{
* Correspondence: sokpesh@yahoo.com

'Department of Pharmacology, School of Medicine and Health Sciences, University for Development Studies, P.O.Box TL 1350, Tamale, Ghana

Full list of author information is available at the end of the article
}

involves the cyclical shedding of the inner lining of the uterus [2]. Onset of menstruation is celebrated in some cultures as it shows the girl is becoming a woman [3]. It however, also heralds a period of inhumane treatment of some post pubescent girl since some cultures and religions consider the menstruating woman as impure leading to forced seclusion, reduced mobility, as well as dietary and social restrictions [2-5]. Some women, before or during menstruation also had to contend with dysmenorrhea which is a painful cramping sensation in the lower abdomen and sometimes accompanied by 
headache, dizziness, diarrhea, bloated feeling, nausea and vomiting, backache and leg pains [6-9]. This menstruation associated pain occurs as a result of excessive production of prostaglandins in the endometrium during the ovulatory cycle which then causes contraction of myometrium, vasoconstriction as well as sensitization of nerve ending $[10,11]$. Dysmenorrhea is classified as primary when there is no evidence of pelvic or hormonal pathology but is secondary when the pain is due to identifiable pathological conditions including endometriosis, ovarian cysts, pelvic inflammatory disease, myomas or intrauterine devices $[9,12]$. Whereas the management of secondary dysmenorrhea requires the treatment of the primary cause, non-pharmacological methods which include fatty diet restriction, exercise, rest, heat application, spinal manipulation, acupuncture, have been reported in several studies to ease the pains of primary dysmenorrhea [1, 12-14]. Medications which provide relief for primary and secondary dysmenorrhea include non-steroidal anti-inflammatory drugs (NSAIDs) such as ibuprofen, naproxen sodium, diclofenac, and mefenamic acid. Other allopathic drugs such as combined oral contraceptives, medications that reduce uterine contraction, dietary supplements and narcotics analgesics had found some role in the management of dysmenorrhea [6, 7]. Prevalence of dysmenorrhea varies widely across the world ranging from 15 to $94 \%[8,9,12,15]$. Dysmenorrhea, which can be so debilitating to disrupt the daily activities, work and schooling of post pubescent females is therefore of public health concern. Several studies have reported various risk factors associated with dysmenorrhea which include age less than 20 years, nulliparity, higher socioeconomic status, heavy menses, depression, smoking, anxiety, and lack of physical activity $[9,12,16]$. The socio-economic impact of dysmenorrhea is rather underestimated and not appreciated by the general populace. Previous studies conducted in Ghana on dysmenorrhea were among pre-tertiary students and a limited number of university students all in southern Ghana. This study is therefore aimed at estimating the prevalence of dysmenorrhea, its impact and management among female students of the Tamale campus of the University for Development Studies in Tamale, northern Ghana.

\section{Method}

\section{Study design and setting}

A self-designed semi-structured questionnaire was used in a cross-sectional study involving students of the Tamale campus of the University for Development studies studying to obtained first degrees in Medicine, Nursing, Midwifery, Health Science Education and Community Nutrition. The questionnaire used in the study which occurred between March and April, 2015 was previously piloted among 20 female students across the fields of study involved in the study. Piloting of questionnaire ensured correction of ambiguous and inconsistent questions before it was administered for the actual data collection. A total of 293 out of 389 (75.3\%) students returned a well completed questionnaire for this study.

\section{Study size determination and sampling procedure}

Sample size was determined using the Cochran's (1977) correction formula for categorical data. $n_{1}=$ $\frac{n_{0}}{1+n_{0} / \text { population }}, \mathrm{n}_{1}=$ required return sample size without estimated response rate factor, $\mathrm{n}_{0}=$ required return sample size according to the Cochran formula; $n_{0}$ $=\frac{(t)^{2} *(p)(1-p)}{(d)^{2}}$ considering sampling error $5 \%(\mathrm{~d}=0.05)$, the significant level $t$-value at alpha level of $0.05(t=1.96)$ and $50 \%$ of respondents estimated to be experiencing monthly dysmenorrhea $(p=0.5)$. With the study population being 990 from a total female population of 1249 on the Tamale campus of the University for Development Studies and using a possible response rate of $70 \%$, the drawn sample size of 389 was obtained for this study. The number of students to be sampled from each class from the first to the final year except the medical students was based on the population of the class. Only the first to third year pre-clinical level medical students who were on the Tamale campus were involved in the study. From an envelope containing pieces of paper which has names and index numbers of all the female students in each class printed on it, the allotted number of respondents were randomly drawn with replacement by the lead researcher or a volunteer from the class.

\section{Statistical analysis}

Data was analyzed using Microsoft Excel and Graph Pad Prism, Version 5.01 (Graph Pad Software Inc., San Diego CA). Chi square test of independence was used to assess the association between the variables. At a confidence interval of $95 \%$, statistical significance was assumed at $p<0.05$.

\section{Results}

\section{Socio-demographic profile}

The socio-demographic profile of the respondents is shown in Table 1. In this study, majority, 221 (75.4\%) were between ages 20 and 25 years (Mean age $=23 \pm$ 5.07 years; Range $=16$ to 48 years), Christians, 208 (71.0\%), and spent their vacation in urban areas of Ghana, 181 (61.8\%). Again, majority, 161 (54.0\%) experienced menarche between ages 13 and 15 (Mean age of menarche $=13.7 \pm 1.87$ years; Range $=9$ to 20 years . 
Table 1 Socio-demographic characteristics of the respondents

\begin{tabular}{|c|c|c|c|}
\hline Variable & Subgroups & $\begin{array}{l}\text { Number of } \\
\text { respondents }\end{array}$ & Percentages \\
\hline \multirow[t]{3}{*}{ Age (years) } & $<20$ & 33 & 11.3 \\
\hline & $20-25$ & 221 & 75.4 \\
\hline & $>25$ & 39 & 13.3 \\
\hline \multirow[t]{3}{*}{ Age of menarche } & $<13$ & 83 & 28.3 \\
\hline & $13-15$ & 161 & 54.0 \\
\hline & $>15$ & 49 & 16.7 \\
\hline \multirow{3}{*}{$\begin{array}{l}\text { Gynecological age } \\
\text { (years) }\end{array}$} & $<5$ & 14 & 4.8 \\
\hline & $5-10$ & 214 & 73.0 \\
\hline & $>10$ & 65 & 22.2 \\
\hline \multirow[t]{2}{*}{ Religious affiliation ${ }^{\text {a }}$} & Christianity & 208 & 71.0 \\
\hline & Islam & 79 & 27.0 \\
\hline \multirow{5}{*}{$\begin{array}{l}\text { Type of } \\
\text { accommodation } \\
\text { at menarche }{ }^{\mathrm{a}}\end{array}$} & Single room & 46 & 15.7 \\
\hline & Chamber and hall & 55 & 18.8 \\
\hline & $\begin{array}{l}\text { Several rooms } \\
\text { in a compound } \\
\text { house }\end{array}$ & 52 & 17.7 \\
\hline & $\begin{array}{l}\text { Self-contained } \\
\text { apartment }\end{array}$ & 126 & 43.0 \\
\hline & Mansion & 10 & 3.4 \\
\hline \multirow{3}{*}{$\begin{array}{l}\text { Area of residence } \\
\text { during vacation }\end{array}$} & Urban area & 181 & 61.8 \\
\hline & Sub-urban & 88 & 30.0 \\
\hline & Rural & 21 & 7.2 \\
\hline
\end{tabular}

${ }^{a}$ There are missing values, so percentage does not add up to 100 . The percentages stated are therefore valid percentages

At menarche, most respondents, 126 (43.0\%) stayed in a self-contained accommodation indicative of their parents and guardians belonging to the middle social class.

\section{Characteristics and impact of menstrual pain on respondents}

The overall prevalence of dysmenorrhea in this study was 83.6\% $(n=245)$. Majority, $138(56.3 \%)$ described their pain as moderate in nature and again for more than half, $143(58.4 \%)$, the pain begins before the outflow of the menstrual blood. The pain lasts less than three days for majority of respondents, 123 (52.6\%) which adversely affects the daily activities of more than half, 150 (61.2\%) of the respondents. The activity most affected, is attendance to lectures (70.7\%). Changes in the breasts such as engorgement, tenderness as well as pain and tingling in the nipples were the most common, 72 (39.1\%) associated symptoms of menstruation. Other notable menstruation associated symptoms reported include diarrhea, 29 (15.8\%), headache, 34 (18.5\%), lethargy, 40 (21.7\%), loss of appetite, $35(19.0 \%)$ as well as nausea, 37 (20.1\%). Only $40(16.3 \%)$ of persons who suffer menstrual pain had ever reported at a hospital. These characteristics and the impact of menstrual pain on daily activities of respondents are shown in Table 2.

Table 2 Characteristics and impact of menstrual pain on respondents

\begin{tabular}{|c|c|c|c|}
\hline Variable & Subgroup & $\begin{array}{l}\text { Number of } \\
\text { respondents }\end{array}$ & Percentage \\
\hline \multirow{2}{*}{$\begin{array}{l}\text { Presence of } \\
\text { dysmenorrhea }\end{array}$} & Yes & 245 & 83.6 \\
\hline & No & 48 & 16.4 \\
\hline \multirow{3}{*}{$\begin{array}{l}\text { Verbal description } \\
\text { of pain }\end{array}$} & Mild & 52 & 21.2 \\
\hline & Moderate & 138 & 56.3 \\
\hline & Severe & 55 & 22.4 \\
\hline \multirow[t]{3}{*}{ When pain begins } & $\begin{array}{l}\text { Before blood } \\
\text { begins to flow }\end{array}$ & 143 & 58.4 \\
\hline & $\begin{array}{l}\text { During the } \\
\text { menstrual flow }\end{array}$ & 98 & 40.0 \\
\hline & $\begin{array}{l}\text { After blood had } \\
\text { stopped }\end{array}$ & 0 & 0.0 \\
\hline \multirow{2}{*}{$\begin{array}{l}\text { Does pain affect } \\
\text { daily activities }\end{array}$} & Yes & 150 & 61.2 \\
\hline & No & 95 & 38.8 \\
\hline \multirow{3}{*}{$\begin{array}{l}\text { How long pain persists } \\
(n=234)\end{array}$} & $<3$ days & 123 & 52.6 \\
\hline & 3 to 5 days & 100 & 42.7 \\
\hline & $>5$ days & 11 & 4.7 \\
\hline \multirow{4}{*}{$\begin{array}{l}\text { Activities affected by } \\
\text { menstrual pain }(n=147)\end{array}$} & Household chores & 82 & 55.8 \\
\hline & $\begin{array}{l}\text { Attendance of } \\
\text { lectures }\end{array}$ & 104 & 70.7 \\
\hline & $\begin{array}{l}\text { Concentration at } \\
\text { lectures }\end{array}$ & 65 & 44.2 \\
\hline & Disturbed Sleep & 60 & 40.8 \\
\hline \multirow{2}{*}{$\begin{array}{l}\text { Do you experience other } \\
\text { symptoms }(n=270)\end{array}$} & Yes & 184 & 62.8 \\
\hline & No & 86 & 29.4 \\
\hline \multirow{15}{*}{$\begin{array}{l}\text { Other menstruation } \\
\text { associated symptoms } \\
\text { experienced }\end{array}$} & Body weakness & 15 & 8.2 \\
\hline & Diarrhoea & 29 & 15.8 \\
\hline & Breast changes & 72 & 39.1 \\
\hline & Fever & 10 & 5.4 \\
\hline & Headache & 34 & 18.5 \\
\hline & Increased appetite & 10 & 5.4 \\
\hline & Irritable & 8 & 4.3 \\
\hline & Lethargy & 40 & 21.7 \\
\hline & Loss of appetite & 35 & 19.0 \\
\hline & Mood swings & 9 & 4.9 \\
\hline & Nausea & 37 & 20.1 \\
\hline & Pains & 29 & 15.8 \\
\hline & Restlessness & 5 & 2.7 \\
\hline & Vomiting & 19 & 10.3 \\
\hline & Others & 22 & 12.0 \\
\hline \multirow{2}{*}{$\begin{array}{l}\text { Ever taken pain } \\
\text { to hospital? }\end{array}$} & Yes & 40 & 16.3 \\
\hline & No & 197 & 80.4 \\
\hline
\end{tabular}


Relationship between menstrual characteristics as well as socio-economic factors and occurrence of dysmenorrhea The relationship between menstrual characteristics as well as socio-economic factors and dysmenorrhea is shown in Table 3. In this study, dysmenorrhea was experienced more by respondents whose age at menarche was less than 13 years than when menarche occurred in later years $\left(89.2 \%\right.$ vrs $80.1 \%-85.7 \% ; \chi^{2}=3.45, \mathrm{df}=2, p=$ 0.178) Again, dysmenorrhea is more prevalent in Christians than followers of Islam (87\% vrs $78.5 \%, p=0.098)$; those who live in self-contained apartment at menarche (middle class) than lower or upper class $(88.9 \%$ vrs $73.9 \%-83.6 \%$; $\chi^{2}=6.16, \mathrm{df}=4, p=0.188$ ); rural dwellers than urban or semi-urban area dweller $(90.5 \%$ vrs $82.9 \%$
- 85.2\%; $\left.\chi^{2}=0.927, \mathrm{df}=2, p=0.629\right)$; those with moderate menstrual flow than the light or heavy flow respondents $\left(84.5 \%\right.$ vrs $62.5 \%-84.2 \% ; x^{2}=2.77, \mathrm{df}=2, p=$ $0.25)$; those whose menstrual flow stops after 5 days than those with shorter number of days of flow $(88.0 \%$ vrs $66.7 \%-83.2 \%, \mathrm{X}^{2}=2.603, \mathrm{df}=2, p=0.272$ ) and respondents who exercise more often than those who do not exercise $(85.6 \%$ vrs $82.0 \%, p=0.053)$ but these differences were not statistically significant. This study however showed that the chronological age of a female is significantly associated with incidence of dysmenorrhea as persons less than 20 years, significantly experience more menstrual pain than their older colleagues $(97.0 \%$ vrs $71.8-83.7 \% ; p=0.016)$.

Table 3 Relationship between menstrual characteristics as well as socio-economic factors and dysmenorrhea

\begin{tabular}{|c|c|c|c|c|}
\hline \multirow[t]{2}{*}{ Variables } & \multirow{2}{*}{$\begin{array}{l}\text { Number of respondents } \\
\text { (percentage) }\end{array}$} & \multicolumn{2}{|c|}{ Presence of dysmenorrhea } & \multirow{2}{*}{$\begin{array}{l}\text { Chi square }(\mathrm{df}) ; \\
p \text {-value }\end{array}$} \\
\hline & & Yes $(n=245)$ & No $(n=48)$ & \\
\hline \multirow[t]{3}{*}{ Age of respondents (years) } & $<20$ & $32(97.0 \%)$ & $1(3.0 \%)$ & \multirow[t]{3}{*}{$8.28(2) ; 0.016^{a}$} \\
\hline & $20-25$ & $185(83.7 \%)$ & $36(16.3 \%)$ & \\
\hline & $>25$ & $28(71.8 \%)$ & $11(28.2 \%)$ & \\
\hline \multirow[t]{3}{*}{ Age of menarche (years) } & $<13$ & $74(89.2 \%)$ & $9(10.8 \%)$ & \multirow[t]{3}{*}{$3.45(2) ; 0.178$} \\
\hline & $13-15$ & $129(80.1 \%)$ & $32(19.9 \%)$ & \\
\hline & $>15$ & $42(85.7 \%)$ & $7(14.3 \%)$ & \\
\hline \multirow[t]{3}{*}{ Gynecological age (years) } & $<5$ & $12(85.7)$ & $2(14.3)$ & \multirow[t]{3}{*}{$10.09(2) ; 0.006^{2}$} \\
\hline & $5-10$ & $187(87.4)$ & $27(12.6)$ & \\
\hline & $>10$ & $46(70.8)$ & $19(29.2)$ & \\
\hline \multirow[t]{2}{*}{ Religious affiliation } & Christianity & $181(87.0 \%)$ & $27(13.0 \%)$ & \multirow[t]{2}{*}{ NA (NA); 0.098} \\
\hline & Islam & $62(78.5 \%)$ & $17(21.5 \%)$ & \\
\hline \multirow[t]{5}{*}{ Type of accommodation at menarche } & Single room & $34(73.9 \%)$ & $12(26.1 \%)$ & \multirow[t]{5}{*}{$6.16(4) ; 0.188$} \\
\hline & Chamber and hall & $46(83.6 \%)$ & $9(16.4 \%)$ & \\
\hline & Several rooms in a compound house & $42(80.8 \%)$ & $10(19.2 \%)$ & \\
\hline & Self-contained apartment & $112(88.9 \%)$ & $14(11.1 \%)$ & \\
\hline & Mansion & $8(80.0 \%)$ & $2(20.0 \%)$ & \\
\hline \multirow[t]{3}{*}{ Area of residence during vacation } & Urban area & $150(82.9 \%)$ & $31(17.1 \%)$ & \multirow[t]{3}{*}{$0.927(2) ; 0.629$} \\
\hline & Sub-urban & $75(85.2 \%)$ & $13(14.8 \%)$ & \\
\hline & Rural & $19(90.5 \%)$ & $2(9.5 \%)$ & \\
\hline \multirow[t]{2}{*}{ Type of menstrual cycle } & Regular & $178(84.0 \%)$ & $34(16.0 \%)$ & \multirow[t]{2}{*}{ NA (NA); 0.572} \\
\hline & Irregular & $61(87.1 \%)$ & $9(12.9 \%)$ & \\
\hline \multirow[t]{3}{*}{ Nature of menstrual flow } & Light & $5(62.5 \%)$ & $3(37.5 \%)$ & \multirow[t]{3}{*}{$2.77(2) ; 0.250$} \\
\hline & Moderate & $207(84.5 \%)$ & $38(15.5 \%)$ & \\
\hline & Heavy & $32(84.2 \%)$ & $6(15.8 \%)$ & \\
\hline \multirow[t]{3}{*}{ Number of days of flow } & $<3$ days & $6(66.7 \%)$ & $3(33.3 \%)$ & \multirow[t]{3}{*}{$2.603(2) ; 0.272$} \\
\hline & $3-5$ days & $188(83.2 \%)$ & $38(16.8 \%)$ & \\
\hline & $>5$ days & $44(88.0 \%)$ & $6(22.0 \%)$ & \\
\hline \multirow[t]{2}{*}{ Level of exercising } & Exercise often & $101(85.6 \%)$ & $17(14.4 \%)$ & \multirow[t]{2}{*}{ NA (NA); 0.053} \\
\hline & Does no exercise & $131(82.0 \%)$ & $41(18.0 \%)$ & \\
\hline
\end{tabular}




\section{Management of menstrual pain by respondents}

As shown in Table 2, up to $83.6 \%$ experience dysmenorrhea but just 40 (16.3\%) had ever sought treatment from the hospital. How these females manage the pain of menstruation is shown in Table 4 . Up to $41.2 \%$ of those who experience menstrual pain bear the pain without any effort to reduce or eliminate it. For those who make effort to manage the pain, majority, 105 (72.9\%) use one product or procedure while the rest use two or three remedies. Alone or together, taking a bed rest was the most commonly used remedy, 76 (52.8\%) while 66 (45.8\%) do with allopathic medicines. Majority, 58 (78.9\%) of users of allopathic medicine did so without prescription from a hospital. Community pharmacies, 25 (43.1\%) and Over-the-counter medicine sellers shop, 24 (41.4\%), were the most common outlets for the procurement of these self-prescribed orthodox medications. Up to $50(86.2 \%)$ of users of self- prescribed medications agree or strongly agree that they always obtain relieve from the menstrual pains on using these medications.

Relationship between bio-data, menstrual characteristics, attitudes and severity of the dysmenorrhea

Respondents between the ages 20 and 25 experienced increasing intensity of pain (Mild $=69.2 \%$, Moderate $=$ $75.4 \%$ and Severe $=81.8 \%$ ) but the difference in relation to other age brackets was not significant $\left(x^{2}=3.104\right.$, $\mathrm{df}=4, p=0.540)$. Menstrual duration $\left(\mathrm{x}^{2}=7.222, \mathrm{df}=4\right.$, $p=0.125)$, and nature of menstrual flow $\left(\chi^{2}=9.005, \mathrm{df}=6\right.$, $p=0.173$ ) showed no association with intensity of pain experienced by respondents. There was however, a significant association between the following variable and likelihood of experiencing the severest form of dysmenorrhea; irregular menstrual flow (Mild $=9.6 \%$, Moderate $=27.3 \%$ and Severe $=36.4 \% ; \chi^{2}=10.54, \mathrm{df}=2$, $p=0.005)$, tendency to seek treatment at the hospital (Mild $=6.0 \%$, Moderate $=6.1 \%$ and Severe $=52.7 \% ; X^{2}=$ 65.61, $\mathrm{df}=2, \quad p<0.0001$ ) and self-medication (Mild $=$ $10.0 \%$, Moderate $=22.1 \%$ and Severe $=56.4 \% ; X^{2}=32.77$, $\mathrm{df}=2$, p, 0.0001). Table 5 showed the relationship between bio-data, menstrual characteristics, attitudes and severity of the dysmenorrhea of the respondents.

\section{Medications used in the management of menstrual pain}

Different types of medications were used by the respondents for the relief of the menstrual pains as shown in Table 6. Alone or present in a compound preparation, paracetamol was the most commonly, 43 (41.3\%) used medication. Non-steroidal anti-inflammatory drugs; diclofenac (18.3\%), ibuprofen (10.6\%), mefenamic acid preparations such as ladinax, menstropain, ponstan, laxinas $(10.3 \%)$ were also used by some of the respondents.

Table 4 Management of menstrual pain by respondents

\begin{tabular}{|c|c|c|c|}
\hline Variable & Subgroup & Number of respondents & Percentage \\
\hline \multirow[t]{2}{*}{ Ever taken pain to hospital? } & Yes & 40 & 16.3 \\
\hline & No & 197 & 80.4 \\
\hline \multirow{7}{*}{$\begin{array}{l}\text { How did you manage your pain in the last three } \\
\text { months ( } n=144 \text { for those who attempted to } \\
\text { manage the pain) }\end{array}$} & Did nothing $(n=245)$ & 101 & 41.2 \\
\hline & Consulted a physician & 11 & 7.6 \\
\hline & Took a bed rest & 76 & 52.8 \\
\hline & $\begin{array}{l}\text { Took orthodox } \\
\text { medication }\end{array}$ & 66 & 45.8 \\
\hline & Took herbal preparation & 5 & 3.5 \\
\hline & Used a heat pad & 12 & 8.3 \\
\hline & Exercised & 21 & 14.6 \\
\hline \multirow[t]{2}{*}{ If you took medication, were they prescribed? $(n=66)$} & Yes & 8 & 12.1 \\
\hline & No & 58 & 78.9 \\
\hline \multirow[t]{5}{*}{ Source of self-medicated drugs } & Community pharmacy & 25 & 43.1 \\
\hline & Over-the-counter medicine & 24 & 41.4 \\
\hline & sellers' shop & & \\
\hline & Friends and relatives & 6 & 10.3 \\
\hline & Others & 2 & 3.4 \\
\hline \multirow[t]{4}{*}{ Always got relieved after self-medicating. } & Strongly agree & 18 & 31.0 \\
\hline & Agree & 32 & 55.2 \\
\hline & Uncertain & 3 & 8.6 \\
\hline & Disagree & 5 & 5.2 \\
\hline
\end{tabular}


Table 5 Relationship between bio-data, menstrual characteristics, attitudes and severity of the dysmenorrhea

\begin{tabular}{|c|c|c|c|c|c|c|}
\hline \multirow[t]{2}{*}{ Variable } & \multirow[t]{2}{*}{ Subgroup } & \multicolumn{3}{|c|}{ Severity of dysmenorrhea } & \multirow[t]{2}{*}{$x^{2}(d f)$} & \multirow[t]{2}{*}{$p$-value } \\
\hline & & Mild & Moderate & Severe & & \\
\hline \multirow[t]{3}{*}{ Age of respondents } & $<20$ & $7(13.5)$ & 19 (13.8) & $6(10.9)$ & $3.104(4)$ & 0.540 \\
\hline & $20-25$ & $36(69.2)$ & $104(75.4)$ & $45(81.8)$ & & \\
\hline & $>25$ & $9(17.3)$ & $15(10.9)$ & $4(7.3)$ & & \\
\hline \multirow[t]{3}{*}{ Age of menarche } & $<13$ & $13(25.0)$ & $43(31.2)$ & $18(32.7)$ & $3.258(4)$ & 0.516 \\
\hline & $13-15$ & $26(50.0)$ & $75(54.3)$ & $28(50.9)$ & & \\
\hline & $>15$ & $13(25.0)$ & $20(14.5)$ & $9(16.4)$ & & \\
\hline \multirow[t]{3}{*}{ Gynecological age (years) } & $<5$ & $4(7.7)$ & $5(3.6)$ & $3(5.5)$ & $1.996(4)$ & 0.737 \\
\hline & $5-10$ & $37(71.2)$ & $109(79.0)$ & $41(74.5)$ & & \\
\hline & $>10$ & $11(21.2)$ & $24(17.4)$ & $11(20.0)$ & & \\
\hline \multirow[t]{3}{*}{ Menses duration } & $<3$ days & $1(2.0)$ & $3(2.2)$ & $2(3.8)$ & $7.222(4)$ & 0.125 \\
\hline & $3-5$ days & $41(80.4)$ & $112(83.6)$ & $35(66.0)$ & & \\
\hline & $>5$ days & $9(17.6)$ & $19(14.2)$ & $16(30.2)$ & & \\
\hline \multirow[t]{2}{*}{ Menstrual pattern } & Regular & $47(90.4)$ & $96(72.7)$ & $35(63.6)$ & $10.54(2)$ & $0.005^{\mathrm{a}}$ \\
\hline & Irregular & $5(9.6)$ & $36(27.3)$ & $20(36.4)$ & & \\
\hline \multirow[t]{3}{*}{ Level of menstrual flow } & Light & $2(3.8)$ & $2(1.5)$ & $1(1.8)$ & $9.005(6)$ & 0.173 \\
\hline & Moderate & $47(90.4)$ & $119(86.9)$ & $41(74.5)$ & & \\
\hline & Heavy & $3(5.8)$ & $16(11.7)$ & $13(23.6)$ & & \\
\hline \multirow[t]{2}{*}{ Visited hospital due to the pain } & Yes & $3(6.0)$ & $8(6.1)$ & $29(52.7)$ & $65.61(2)$ & $<0.0001^{\mathrm{a}}$ \\
\hline & No & $47(94.0)$ & $124(93.3)$ & $26(47.3)$ & & \\
\hline \multirow[t]{2}{*}{ Practised self- medication? } & Yes & $5(10.0)$ & $30(22.1)$ & $31(56.4)$ & $32.77(2)$ & $<0.0001^{\mathrm{a}}$ \\
\hline & No & $45(90.0)$ & $106(77.9)$ & $24(43.6)$ & & \\
\hline
\end{tabular}

astatistically significant

Table 6 Drugs used in the management of the pain in the last three menstrual cycle

\begin{tabular}{|c|c|c|c|}
\hline Variable & Subgroup & Number & Percentage \\
\hline \multirow[t]{7}{*}{ Medication used for self -medication } & Paracetamol & 43 & 41.3 \\
\hline & Mefenamic acid preparation & 11 & 10.6 \\
\hline & Diclofenac & 19 & 18.3 \\
\hline & Hyoscine butylbromide (Buscopan) & 7 & 6.7 \\
\hline & Ibuprofen & 11 & 10.6 \\
\hline & Herbal preparations & 4 & 3.8 \\
\hline & Others & 9 & 8.7 \\
\hline \multirow[t]{6}{*}{ Persons who recommended these drugs } & Self & 47 & 50.5 \\
\hline & Prescriber & 9 & 9.7 \\
\hline & Nurse & 7 & 7.5 \\
\hline & Mother & 8 & 8.6 \\
\hline & Friends & 9 & 9.7 \\
\hline & Pharmacist & 13 & 14.0 \\
\hline \multirow[t]{2}{*}{ Dosage assessment } & Correct & 44 & 42.3 \\
\hline & Incorrect & 60 & 57.7 \\
\hline
\end{tabular}


Antispasmodic, hyoscine butylbromide was used by a few of the respondents (6.7\%). In most times, 47 (50.5\%) that a respondent engaged in self -medication, they depended on their own knowledge but in 13 (14.0\%) cases of self -medication, they got the medication based on the recommendation of the pharmacist. Comparing the doses stated by the respondents with that in the British National Formulary, the dosage regimen applied by the respondents was incorrect in most cases (57.7\%).

\section{Classes of medication for managing dysmenorrhea based on severity of pain}

The medications used for managing dysmenorrhea based on severity of pain are presented in Fig. 1. The number of occasions that the various classes of medication were used by the respondents based on whether the pain was mild, moderate or severe were diclofenac $(0,8,13)$, paracetamol $(4,22,17)$, ibuprofen $(0,5,11)$, mefenamic acid $(0,3,12)$, hyoscine butylbromide $(1,3,3)$ and others $(2,3,6)$. Paracetamol preparations were the most commonly used (38.1\%) class of medication for all the types of dysmenorrhea and followed by diclofenac preparations (18.6\%).

\section{Discussions}

Menstruation is considered a private issue in many cultures hence its associated complaints are borne silently by most post-pubescent females. For some women, they experience a monthly ritual of lower abdominal pain during menstruation known as dysmenorrhea. This study found a high prevalence of dysmenorrhea $(83.6 \%$ ) which is comparable to $85.0 \%$ recorded in United States of America (USA) [17] and $84.1 \%$ in Italy [9]. An earlier study among secondary school students in Accra, Ghana recorded a lower prevalence rate of $74.4 \%$ [18]. Studies in some other countries recorded lower rates between 38.1 and $76.0 \%[1,6,12,19,20]$ but higher prevalence rates of 92.5 and $94 \%$ were respectively reported in Taiwan and Oman $[8,21]$. The varying prevalence rates of dysmenorrhea across the world could be attributed to the use of different categories of subjects as well as the lack of a universally accepted definition of dysmenorrhea. Majority of respondents in this study described their menstrual pain as moderate similar to studies in Italy and Oman $[8,9]$ but in some studies, majority classified their pain as mild $[6,11]$. Pain perception and expression of pain is influenced by genetics, psychological, developmental, familial, social and cultural factors [22-24]. Therefore, the aforementioned factors as well as variability of pain threshold of the different categories of respondents who participated in all these studies could account for the differences in the description of their pains. Dysmenorrhea in this study affected the daily life activities of twothirds of the female students including school attendance as reported similarly in several studies across the world $[1,6,8,9,12,13]$. Attending lectures was the most disrupted daily life activity for respondents in this study and even if they make it to the lectures, their concentration was greatly disturbed due to the dysmenorrhea. Just as reported in several studies on dysmenorrhea, two-third of subjects in this study experience menstruation associated symptoms such as diarrhea, headaches, lethargy, loss of appetite, nausea, joint and body pains, vomiting but the most common symptom was changes in the breast such as tenderness, heaviness, engorgement, as well as tingling and painful nipples which occurred in $39.1 \%$ of respondents $[1,12,21]$. This study did not find any significant association between incidence of dysmenorrhea and socio-demographic characteristics such religious affiliation, socio-economic status at menarche and locality of residence. This study however found a significant association between a respondent experiencing dysmenorrhea and the chronological as well as gynecological ages which was also reported in other studies which showed that incidence of dysmenorrhea decreases with increasing chronological age or gynecological age [16, 25]. Type
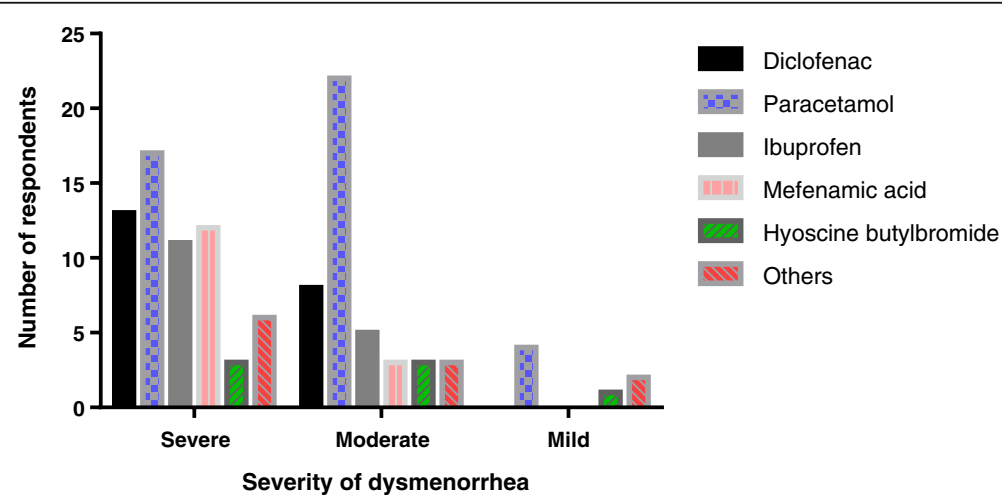

Fig. 1 Classes of medication for managing dysmenorrhea based on severity of pain 
of menstrual cycle, nature of the menstrual flow, number of days of menstrual flow and exercise did not predict the presence or absence of dysmenorrhea in this study. It would have been expected that the undesirable effects of dysmenorrhea and menstruation associated symptoms on the activities of respondents, would cause them to be eager to visit the hospital but only $16.3 \%$ ever did so. Similar hospital attendance rates between 12.1 and $18.0 \%$ were reported in Iran, Malaysia, Nigeria, Turkey and the USA $[2,10,14,17,26]$. A mere 3\% was even recorded in Oman [8]. Self-treatment of menstrual pain using mostly non-steroidal antiinflammatory drugs and antispasmodic drugs seem to be the most common practice in many countries $[2,6,8,10$, $12,14,26,27]$. The self-treatment of dysmenorrhea by many women rather than visit a hospital is because many consider the pain as normal thus not worth taking to a hospital where they may join long queues to consult a physician. Again, many who self-medicate get relieve from the use of these medications as shown in this study. In this study, up to four-fifth of users of non-prescribed medications stated that they always get relieved of their pains after using these medications although the dosage regimen followed by three-fifth of the users were not appropriate. The suggestion by $86.2 \%$ of the females that they get relieved even with the high level of incorrect dosage regimen could be due to a challenge of recall of the correct dosage regimen or the healing could be due to the placebo effect [28]. Contrary to other studies, this study did not find any significant relationship between pain intensities suffered by respondents and their biological age, age at menarche, gynecological age, nature and duration of menstrual flow $[1,6,25,29]$. There was rather an association between the menstrual pattern and severity of dysmenorrhea as recorded in other studies in which persons with irregular menstrual pattern suffered a more severe form of menstrual pain $\left(\chi^{2}=10.54 ; \mathrm{df}=2\right.$; $p=0.005$ ) [6]. This study also found that females with severe dysmenorrhea exhibited a significantly greater tendency to seek treatment at the hospital $\left(x^{2}=65.61\right.$; $\mathrm{df}=2 ; p<0.0001)$ or self-medicate $\left(\mathrm{X}^{2}=32.77 ; \mathrm{df}=2\right.$; $\mathrm{p}<0.0001)$. The classes of drugs used for the dysmenorrhea did not significantly differ. Paracetamol (Acetaminophen) or its combination preparation was the most patronized analgesic notwithstanding the severity of the menstrual pain. The use of paracetamol for the management of dysmenorrhea was also reported in some earlier studies [8, 10, 26, 27]. Paracetamol, although exhibits a weaker analgesic effect than NSAIDs, it is better tolerated and has better safety profile [30] and could be appropriate for managing dysmenorrhea in females who are at risk of peptic ulcer or asthma; conditions for which NSAIDs are contraindicated.

\section{Conclusions}

Dysmenorrhea is a major menstruation related complaint among the female university students in northern Ghana. A significant association exists between the chronological and gynecological ages of respondents with younger students experiencing dysmenorrhea a lot more. Irregular menstruation is significantly associated with the severest form of dysmenorrhea but the chronological age, age at menarche or socio-economic disposition of the respondent do not. Dysmenorrhea and the menstruation associated symptoms adversely affect the daily lives of the females with some missing school. Although bed rest was the most applied modality, allopathic medication especially paracetamol preparations were used especially by those with moderate form of dysmenorrhea.

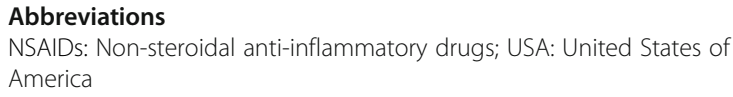

\section{Acknowledgements}

Authors wish to acknowledge the role of Miss Patience Asupulie Akayila and Miss Fati Abdulai-Inusah both final year BSc. Nursing students of the University for Development who assisted in the piloting and collection of the completed questionnaires.

\section{Funding}

All expenses were borne by the authors.

\section{Availability of data and materials}

The datasets used and/or analysed during the current study are available from the corresponding author on reasonable request.

\section{Authors' contributions}

EPKA conceived the idea, collected the data, did the analysis and drafted the manuscript. BSM and AA drafted the manuscript. All authors read and approved the final manuscript.

\section{Ethics approval and consent to participate}

Prior approval for this study was obtained from the Ethics Committee of the School of Medicine and Health Sciences of the University for Development Studies. Verbal consent was obtained from the respondents to enhance confidentiality of the research which increased their participation. The introductory section of the questionnaire informed respondents that accepting to participate and completing the questionnaire indicated consent and that they have the option to withdraw at any point in the research.

\section{Consent for publication}

Not applicable.

\section{Competing interests}

The authors declare that they have no competing interests.

\section{Publisher's Note}

Springer Nature remains neutral with regard to jurisdictional claims in published maps and institutional affiliations.

\section{Author details}

'Department of Pharmacology, School of Medicine and Health Sciences, University for Development Studies, P.O.Box TL 1350, Tamale, Ghana.

${ }^{2}$ Department of Health Professions Education and Innovative Learning, School of Medicine and Health Sciences, University for Development Studies, Tamale, Ghana. 
Received: 25 August 2015 Accepted: 8 February 2018

Published online: 13 February 2018

\section{References}

1. Kumbhar SK, Reddy M, Sujana B, Roja RK, Divya BK, Balkrishna C. Prevalence of dysmenorrhoea among adolescent girls (14-19 yrs) of Kadapa district and its impact on quality of life: a cross sectional study. National J Community Med. 2011;2(2):265-8.

2. Poureslami M, Osati-Ashtiani F. Assessing knowledge, attitudes and behaviour of adolescent girls in sub-urban districts of Tehran about dysmenorrhea and menstrual hygiene. J Int Womens Stud. 2002;3(2):51-61.

3. Bhartiya A. Menstruation, religion and society. Int J of Soc Sci Humanit. 2013;3(6):523-7.

4. UNICEF. Menstrual hygiene in schools in 2 countries of Francophone West Africa - Burkina Faso and Niger case studies in 2013. Available at http:// www.unicef.org/wash/schools/files/MHM_study_report_Burkina_Faso_and_ Niger_English_Final.pdf. Accessed 10 July 2015.

5. Anusree PC, Ardra R, Aswathy BS, Faseela VCM, Gincy PB, Anupama T. Knowledge regarding menstrual hygiene among adolescent girls in selected schools, Mangalore with a view to develop an information booklet. J Nurs Health Sci. 2014;3(1):55-60.

6. El-Gilany AH, Badawi K, El-Fedawy. Epidemiology of dysmenorrhea among adolescent students in Mansoura, Egypt. East Mediterr Health J. 2005;11(1/ 2):155-63.

7. Mannix LK. Menstrual-related pain conditions: dysmenorrhea and migraine. J Women's Health. 2008:17(5):879-91.

8. Al-Kindi R, Al-Bulushi A. Prevalence and impact of dysmenorrhea among Omani high school students. SQU Medical J. 2011;11(4):485-91.

9. Grandi G, Ferrari S, Xholli A, Cannoletta M, Palma F, Romani C, Volpe A, Cagnacci A. Prevalence of menstrual pain in young women: what is dysmenorrhea? J Pain Res. 2012;5:169-74.

10. Cakir M, Mungan I, Karakas T, Girisken I, Okten A. Menstrual pattern and common menstrual disorders among university students in Turkey. Pediat Int. 2007:49:938-42. https://doi.org/10.1111/j.1442-200X.2007.02489.x.

11. Singh A, Kiran D, Singh $H$, Nel B, Singh $P$, Tiwari P. Prevalence and severity of dysmenorrhea: a problem related to menstruation, among first and second year female medical students. Indian J Physiol Pharmacol. 2008; 252(4):389-97.

12. Charu S, Amita R, Sujoy R, Thomas GA. Menstrual characteristics and prevalence and effect of dysmenorrhea on quality of life of medical students. Int J Collab Res Intern Med Public Health. 2012;4(4):276-94.

13. Baghianimoghadam MH, Loo AM, Falahzadeh H, Alavijeh MM. A survey about the prevalence of dysmenorrhea in female students of Shahid Sadoughi University of Medical Sciences and their knowledge and practice toward it. J Commun Health Res. 2012;1(2):93-8.

14. Wong LP. Attitudes towards dysmenorrhea, impact and treatment seeking among adolescent girls: a rural school-based survey. Aust J Rural Health. 2011:19:218-23.

15. Harlow SD, Campbell OM. Epidemiology of menstrual disorders in developing countries: a systematic review. BJOG: An Int J Obstet Gynaecol. 2004;111(1):6-16

16. Patel V, Tanksale V, Sahasrabhojanee M, Gupte S, Nevrekar P. The burden and determinants of dysmenorrhoea: a population-based survey of 2262 women in Goa, India. BJOG Int J Obstet Gynaecol. 2006;113(4):453-63.

17. Banikarim C, Chacko MR, Kelder SH. Prevalence and impact of dysmenorrhea on Hispanic female adolescents. Arch Pediatr Adolesc Med. 2000;154:1226-9.

18. Gumanga SK, Kwame-Aryee RA. Menstrual characteristics in some adolescent girls in Accra, Ghana. Ghana Med J. 2012;46(1):3-7.

19. Ortiz Ml. Primary dysmenorrhea among Mexican university students: prevalence, impact and treatment. Eur J Obstet Gynecol Reprod Biol. 2010; 152(1):73-7.

20. Unsal A, Unal A, Tozun M, Arslan G, Calik E. Prevalence of dysmenorrhea and its effect on quality of life among a group of female university students. Ups J Med Sci. 2010;115:138-45.

21. Cheng $H$, Lin $Y$. Selection and efficacy of self-mangement strategies for dysmenorrhea in young Taiwanese women. J Clin Nurs. 2010;20:1018-25.

22. Edwards CL, Fillingim RB, Keefe F. Race, ethnicity and pain. Pain. 2001;94(2): 133-7.

23. Mannion AF, Balagué $F$, Pellisé $F$, Cedraschi $C$. Pain measurement in patients with low back pain. Nat Clin Pract Rheumatol. 2007;3(11):610-8.
24. McGrath PA. Psychological aspects of pain perception. Arch Oral Biol. 1994; 39:S55-62.

25. Loto OM, Adewumi TA, Adewuya AO. Prevalence and correlates of dysmenorrhea among Nigerian college women. Aust N Z J Obstet Gynaecol. 2008;48:442-4. https://doi.org/10.1111/j.1479-828X.2008.00869.x.

26. Okoro RN, Malgwi H, Ngong CK, Okoro GO. Dysmenorrhoea: ways of management among Nigerian University students. Actual Gynaecol. 2012;4: 106-13.

27. Sapkota AR, Coker ME, Goldstein RER, Atkinson NL, Sweet SJ, Sopeju PO, Ojo KK. Self-medication with antibiotics for the treatment of menstrual symptoms in southwest Nigeria: a cross-sectional study. BMC Public Health. 2010;10(1):610.

28. Stewart-Williams S, Podd J. The placebo effect: dissolving the expectancy versus conditioning debate. Psychol Bull. 2004;130(2):324.

29. Yamamoto K, Okazaki A, Sakamoto Y, Funatsu M. The relationship between premenstrual symptoms, menstrual pain, irregular menstrual cycles and psychosocial stress among Japanese college students. J Physiol Anthropol. 2009;28(3):129-36

30. Graham GG, Davies MJ, Day RO, Mohamudally A, Scott KF. The modern pharmacology of paracetamol: therapeutic actions, mechanism of action, metabolism, toxicity and recent pharmacological findings. Inflammopharmacology. 2013;21(3):201-32.

\section{Submit your next manuscript to BioMed Central and we will help you at every step:}

- We accept pre-submission inquiries

- Our selector tool helps you to find the most relevant journal

- We provide round the clock customer support

- Convenient online submission

- Thorough peer review

- Inclusion in PubMed and all major indexing services

- Maximum visibility for your research

Submit your manuscript at www.biomedcentral.com/submit
Biomed Central 